\title{
Studies on vision and visual dysfunction: a Special Issue to honor the careers of Barry Lee and Dora Fix Ventura
}

\author{
Luiz Carlos L. Silveira and Bruno Duarte Gomes
}

Universidade Federal do Pará, Belém, PA, Brazil

This special issue of Psychology \& Neuroscience celebrates the career of Barry Buchanan Lee and Dora Selma Fix Ventura. It follows the Second International Symposium on Vision and Visual Dysfunction and the School for Advanced Studies on Vision and Visual Dysfunction held in 2010 in Belém, supported by CAPES, CNPq, and FAPESPA. During these events, 23 scientists from seven countries met in Belém to present the most recent achievements in our understanding of the visual system and discuss the current theories and hypotheses about how vision works, its mechanisms, diagnostic methods, and the treatment of visual dysfunction.

This special issue of Psychology \& Neuroscience continues and expands the information presented in Belém by publishing several studies on related subjects: "GABA and glutamate transporters: new events and function in the vertebrate retina" (do Nascimento, Sawada, Oliveira, Crespo-Lopez, Herculano, Hamoy, Silva, Bastos, and Soeiro-Pantoja), "The genetics of New World monkey visual pigments" (Bonci, Neitz, Neitz, Silveira, and Ventura), "Asymmetries in the contributions of On- and Off-mechanisms to the ERG signal" (Kremers), "Human photopic ON- and OFFERG responses elicited by square wave and sawtooth stimuli" (Kremers and Pangeni), "Colour signals in retina and lateral geniculate nucleus of marmoset monkeys (review)" (Martin and Grünert), "The contrast sensitivity of pattern transient VEP components: contribution from M and P pathways" (Souza, Gomes, Lacerda, Saito, da Silva Filho, and Silveira), "Effect of contrast and gaps between Vernier stimulus element

Luiz Carlos L. Silveira, Universidade Federal do Pará, Núcleo de Medicina Tropical and Instituto de Ciências Biológicas, Belém, Brazil. Bruno D. Gomes, Universidade Federal do Pará, Instituto de Ciências Biológicas, Belém, Brazil. Correspondence regarding this paper should be directed to: Dr. Luiz Carlos de Lima Silveira, Universidade Federal do Pará, Núcleo de Medicina Tropical, Av. Generalíssimo Deodoro, no. 92 (Umarizal), Belém, Pará, 66055-240, Brazil. Phone: +55 91-32016819. Fax: +55 91-32410032. E-mail: luiz@ufpa.br on sweep VEP measurements of human cortical Vernier responses" (Hamer, Carvalho, and Ventura), "Neurophysiological correlates of colour perception" (Valberg and Seim), "Functional vision barriers: a new concept analyzed in terms of human visual performance" (Colombo, O’Donell, Santillán, and Issolio), and "Early visual changes in diabetic patients with no retinopathy as measured by color discrimination and electroretinography" (Gualtieri, Nishi, Lago, and Ventura).

\section{Contributions made by Barry Lee and Dora Fix Ventura to the study of vision and visual dysfunction}

Barry Lee has been working with one of the most important aspects of visual system organization: information transfer through retinal ganglion cells. Most of his work has been performed in the primate retina in catarrhines and platyrrhines, the so-called Old World and New World monkeys, respectively. He took advantage of the fact that the retina is an ideal locus for an interdisciplinary approach to visual science. In the retina, physiology, anatomy, and cell biology can be compared on a one-to-one basis, and the relationships between them can be firmly established. Additionally, retinal physiology can be used as a first step to understanding cortical processing and human psychophysics. He recorded from retinal elements and used the results to model retinal processing and perceptual performance (Lee, Martin, \& Valberg, 1988; Lee, Martin, \& Valberg, 1989a,b,c; Valberg, Lee, Kaiser, $\&$ Kremers, 1992). His works helped to establish the physiological basis for the red-green, blue-yellow, and black-white dimensions of color vision (Lee et al., 1988, 1989a,b,c; Valberg et al., 1992; Lee, Pokorny, Smith, Martin, \& Valberg, 1990; Kremers, Lee, \& Kaiser, 1992; Smith, Lee, Pokorny, Martin, \& Valberg, 1992; Dacey, \& Lee, 1994; Dacey, Lee, Stafford, Pokorny, \& Smith, 1996). In a recent series of experiments, he showed that the degradation of color vision in the peripheral visual field is not attributable to retinal processing but rather must originate through cortical mechanisms (Martin, Lee, White, Solomon, \& Rüttiger, 2001). Barry Lee has 
also been interested in the evolution of color vision, recording from retinal ganglion cells in New World and Old World monkeys and comparing the retinal organization in these primates that exhibit different forms of color vision: full trichromats (e.g., Old World monkeys and howler monkeys [Saito, da Silva Filho, Lee, Bowmaker, Kremers, \& Silveira, 2004]), mixed populations of trichromats and dichromats (e.g., capuchin monkeys [Lee, Silveira, Yamada, \& Kremers, 1996; Silveira et al., 1999; Lee et al., 2000] and marmosets [Yeh et al., 1995]), and monochromats (e.g., owl monkeys [Silveira, Lee, Kremers, da Silva Filho, Saito, \& Kilavik, 2000]). Thus, studying the differences in retinal organization among these primates may help us understand how and why trichromacy evolved in this group of mammals (Lee, 2004).

Barry Lee obtained a B.A. in Physiology and Psychology at Oxford University of Oxford in 1967 and a Ph.D. in Physiology from the Faculty of Medicine, University of London in 1971. He was an M.R.C. Scholar in the Department of Physiology and Pharmacology at the National Institute for Medical Research, London (1967-1970), a Teaching Assistant at University College London (1968-1969), a Research Associate in the Center for Brain Research at the University of Rochester, New York (1971-1973), a Welcome Travelling Research Fellow at the Max Planck Institute for Biophysical Chemistry, Göttingen (1974-1975), a Staff Member and then Group Leader at the Max Planck Institute for Biophysical Chemistry (1975-present), and a Professor of Biological Sciences at the State University of New York, College of Optometry (2000-present).

Barry Lee is a member of important scientific societies including the Society for Neuroscience, Federation of European Neuroscience Society, Association for Research in Vision and Ophthalmology, Optical Society of America, International Colour Vision Society, and German Neuroscience Society. He has been on the Directorial Board of the International Color Vision Society since 1998 and on the Program Committee of the Optical Society of America since 2003. He has received several prizes and awards during his career including the Verriest Medal of the International Colour Vision Society for his significant contribution to the advancement of several aspects of color vision research (2007; Figure 1), the Rank Prize for Optoelectronics, Institute of Physics, London, with Vivianne C. Smith, Joel Pokorny, and Dennis Dacey in recognition of their work on new pathways in the visual system (2004), a Fellow of the Optical Society of America (1996), and a Distinguished Visiting Lecturer, York University, Toronto (1990).

Dora Fix Ventura is one of the most important Brazilian neuroscientists and has dedicated most of her career to the study of the visual system. She created the Sensory Psychophysiology Laboratory at the Psychology Institute, University of São Paulo, in 1968, which is dedicated to the study of the neural mechanisms of vision using behavioral and electrophysiological

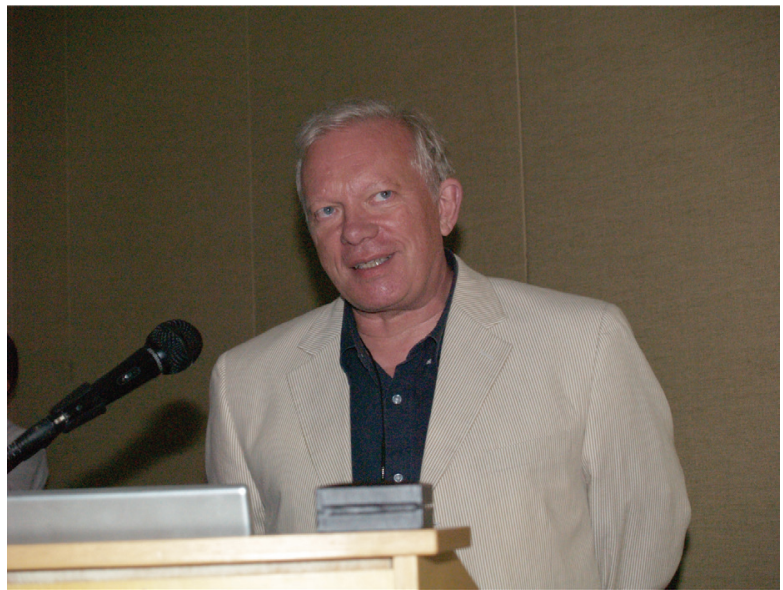

Figure 1. Barry Lee speaking at the Verriest Lecture during the $19^{\text {th }}$ Symposium of the International Colour Vision Society, Belém, Pará (1997). He was awarded the Verriest Medal by the Society in 1997. The Medal is presented at each Symposium to an individual who has made a significant contribution to the advancement of one or more aspects of color vision research.

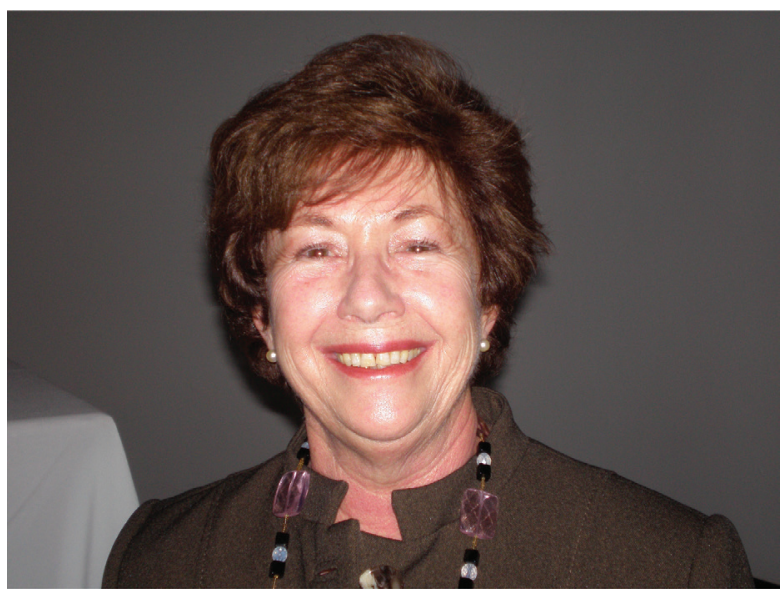

Figure 2. Dora Selma Fix Ventura was awarded the Neuroscience Medal during the $34^{\text {th }}$ Symposium of the Brazilian Society for Neuroscience and Behaviour, Caxambu, Minas Gerais (2010). The Medal is presented at each symposium to a Brazilian scientist who has made a significant contribution to the advancement of one or more aspects of nervous system research.

methods (Rocha, Saito, Silveira, de Souza, \& Ventura, 2008). Subsequently, in the 1990s, she created the Laboratory of Vision at the same institution, which is dedicated to applied research in Clinical Psychophysics and Clinical Visual Electrophysiology for the study of neurodegenerative diseases of the visual system. These diseases comprise a group of visual dysfunctions that are attributable to genetic, metabolic, or neurotoxic causes such as Duchenne muscular dystrophy (Costa, Oliveira, Feitosa-Santana, Zatz, \& Ventura, 2007), Leber optical neuropathy (Ventura et al., 2007), multiple sclerosis (Moura et al., 2008), diabetes (Gualtieri, Bandeira, Hamer, Damico, Moura, \& Ventura, 2011), and mercury intoxication (Costa et al., 2012). To perform such studies, she leads a group of young scientists and 
students who actively pursue national and international collaborations (Goulart, Bonci, Galvão, Silveira, \& Ventura, 2013).

Dora Fix Ventura is a graduate of the Department of Psychology in the Faculty of Philosophy, Science and Literature at the University of São Paulo (1961) and obtained an M.A. (1964) and Ph.D. (1968) in Experimental Psychology at Columbia University, New York. She has been very active in several scientific societies including the Brazilian Society for the Advancement of Science, Federation of Experimental Biology Societies, Brazilian Society for Neuroscience and Behavior, Brazilian Research Association in Vision and Ophthalmology, Association for Research in Vision and Ophthalmology, International Colour Vision Society, and International Brain Research Organization. She was President of the Federation of Experimental Biology Societies from 1996 to 2001 and President of the Brazilian Society for Neuroscience and Behavior from 1991 to 1994 . She was elected as a member of the Brazilian Academy of Sciences and received several prizes and awards including the Grã Cruz of the National Order of Scientific Merit (1998), CAPES 50 Years Medal (2001), and Neuroscience Medal (2010).

Dora Fix Ventura has taught Experimental Psychology and Neuroscience in the Department of Experimental Psychology, Institute of Psychology, University of São Paulo since 1968, progressively occupying higher positions in her career, culminating in becoming a Full Professor and Chair of the department. She is presently retired but maintains active collaborations that contribute to teaching and research in the department.

\section{Acknowledgements}

LCLS is a CNPq research fellow.

\section{References}

Costa, M. F., Oliveira, A. G. F., Feitosa-Santana, C., Zatz, M., \& Ventura, D. F. (2007). Red-green color vision impairment in Duchenne muscular dystrophy. American Journal of Human Genetics, 80, 1064-1075.

Costa, T. L., Barboni, M. T. S., Moura, A. L. A., Bonci, D. M. O., Gualtieri, M., de Lima Silveira, L. C., Ventura, D. F. (2012). Longterm occupational exposure to organic solvents affects color vision, contrast sensitivity and visual fields. PLoS One, 7, e42961.

Dacey, D., \& Lee, B. B. (1994). The "blue-ON" pathway in primate retina originates from a distinct bistratified ganglion cell type. Nature, 367, 731-735.

Dacey, D. M., Lee, B. B., Stafford, D. K., Pokorny, J., \& Smith, V. C. (1996). Horizontal cells of the primate retina: Cone specificity without spectral opponency. Science, 271, 656-659.

Goulart, P. R. K., Bonci, D. M. O., Galvão, O. F., Silveira, L. C. L., \& Ventura, D. F. (2013). Color discrimination in the tufted capuchin monkey, Sapajus spp. PLoS One, 8, e62255.

Gualtieri, M., Bandeira, M. L., Hamer, R. D., Damico, F. M., Moura, A. L. A., \& Ventura, D. F. (2011). Contrast sensitivity mediated by inferred magno- and parvocellular pathways in type 2 diabetics with and without nonproliferative retinopathy. Investigative Ophthalmology \& Visual Science, 52, 1151-1155.
Kremers, J., Lee, B. B., \& Kaiser, J. (1992). Sensitivity of macaque retinal ganglion cells and human observers to combined luminance and chromatic temporal modulation. Journal of the Optical Society of America A, 9, 1477-1485.

Lee, B. B. (2004). Paths to colour in the retina. Clinical and Experimental Optometry, 87, 239-248.

Lee, B. B., Martin, P. R., \& Valberg, A. (1988). The physiological basis of heterochromatic flicker photometry demonstrated in the ganglion cells of the macaque retina. Journal of Physiology (London), 404, 323-347.

Lee, B. B., Martin, P. R., \& Valberg, A. (1989a). Nonlinear summation of M- and L-cone inputs to phasic retinal ganglion cells of the macaque. Journal of Neuroscience, 9, 1433-1442.

Lee, B. B., Martin, P. R., \& Valberg, A. (1989b). Sensitivity of macaque ganglion cells to chromatic and luminance flicker. Journal of Physiology (London), 414, 223-243.

Lee, B. B., Martin, P. R., \& Valberg, A. (1989c). Amplitude and phase of responses of macaque ganglion cells to flickering stimuli. Journal of Physiology (London), 414, 245-263.

Lee, B. B., Pokorny, J., Smith, V. C., Martin, P. R., \& Valberg, A. (1990) Luminance and chromatic modulation sensitivity of macaque ganglion cells and human observers. Journal of the Optical Society of America A, 7, 2223-2236.

Lee, B. B., Silveira, L. C. L., Yamada, E., Hunt, D. M., Kremers, J., Martin, P. R., Troy, J., \& da Silva-Filho, M. (2000). Visual response of ganglion cells of a New-World primate, the capuchin monkey, Cebus apella. Journal of Physiology (London), 528, 573-590.

Lee, B. B., Silveira, L. C. L., Yamada, E. S., \& Kremers, J. (1996). Parallel pathways in the retina of Old- and New World primates. Revista Brasileira de Biologia, 56, 323-338.

Martin, P. R., Lee B. B., White, A. J. R., Solomon, S. G., \& Rüttiger, L. (2001). Chromatic sensitivity of ganglion cells in the peripheral primate retina. Nature, 410, 933-936.

Moura, A. L. A., Teixeira, R. A. A., Oiwa, N. N., Costa, M. F., FeitosaSantana, C., Callegaro, D., Hamer, R. D., \& Ventura, D. F. (2008). Chromatic discrimination losses in multiple sclerosis patients with and without optic neuritis using the Cambridge Colour Test. Visual Neuroscience, 25, 463-468.

Rocha, F. A. F., Saito, C. A., Silveira, L. C. L., de Souza, J. M., \& Ventura, D. F. (2008). Twelve chromatically opponent ganglion cell types in turtle retina. Visual Neuroscience, 25, 307-315.

Saito, C. A., da Silva Filho, M., Lee, B. B., Bowmaker, J. K., Kremers, J., \& Silveira, L. C. L. (2004). Alouatta trichromatic color vision: Single-unit recording from retinal ganglion cells and microspectrophotometry. Investigative Ophthalmology \& Visual Science, 45, E-Abstract 4276-B737.

Silveira, L. C. L., Lee, B. B., Kremers, J., da Silva Filho, M., Saito, C. A., \& Kilavik, B. E. (2000). Receptor inputs and temporal dynamics of owl monkey ganglion cells. Investigative Ophthalmology \& Visual Science, 41, S937.

Silveira, L. C. L., Lee, B. B., Yamada, E. S., Kremers, J., Hunt, D. M., Martin, P. R., \& Gomes, F. L. (1999). Ganglion cells of a shortwavelength cone pathway in New World monkeys: Morphology and physiology. Visual Neuroscience, 16, 333-343.

Smith, V. C., Lee, B. B., Pokorny, J., Martin, P. R., \& Valberg, A. (1992). Responses of macaque ganglion cells to the relative phase of heterochromatically modulated lights. Journal of Physiology (London), 458, 191-221.

Valberg, A., Lee, B. B., Kaiser, P. K., \& Kremers, J. (1992). Responses of macaque ganglion cells to movement of chromatic borders. Journal of Physiology (London), 458, 579-602.

Ventura, D. F., Gualtieri, M., Oliveira, A. G. F., Costa, M. F., Quiros, P., Sadun, F., de Negri, A. M., Salomão, S. R., Berezovsky, A., Sherman, J., Sadun, A. A., \& Carelli, V. (2007). Male prevalence for color vision defects in Leber's hereditary optic neuropathy asymptomatic carriers of the $11778 / \mathrm{ND} 4$ mutation. Investigative Ophtalmology \& Visual Science, 48, 2362-2370.

Yeh, T., Lee, B. B., Kremers, J., Cowing, J. A., Hunt, D. M., Martin, P. R., \& Troy, J. B. (1995). Visual responses in the lateral geniculate nucleus of dichromatic and trichromatic marmosets (Callithrix jacchus). Journal of Neuroscience, 15, 7892-7904. 